\title{
Methodological Bases of Advanced Geo-ecological Problems Resolving in Neo-industrial Clusters
}

\author{
Tyulenev Maxim A. ${ }^{\mathrm{a}}$, Lesin Yury V. \\ Vik Svetlana V. ${ }^{\mathrm{c}}$ \\ T. F. Gorbachev Kuzbass State Technical University, \\ Kemerovo, Russian Federation \\ a tma.geolog@kuzstu.rub lyuv.geo@kuzstu.ru \\ cotdelad@mail.ru
}

\author{
Zhironkin Sergey A. \\ T. F. Gorbachev Kuzbass State Technical University, \\ Kemerovo, Russian Federation \\ National Research Tomsk Polytechnical University \\ Tomsk, Russian Federation \\ zhironkin@inbox.ru
}

\begin{abstract}
The importance of geo-ecological studies is confirmed by an insufficient readiness of methodological approaches and conceptual bases of research of geo-ecological factors of innovative development of industrial clusters at the market transformation stage of the Russian economy, the analysis of regularities, factors and mechanisms of state regulation of "external effects" of economic growth. Along with it, the impossibility of direct borrowing of ready forms and institutes of government regulation of geo-ecological factors of innovative development in industrial clusters used abroad increases the importance of carrying out similar researches in Russia. So, technological and economic potential of Kuzbass - the most agglomerated industrial cluster of Western Siberia, Russia - should be used for investment in researching of transition to green economy and environment-saving mining, metallurgy and organic chemistry. The most perspective way of initiating geo-ecological development of industrial clusters is its neo-industrialization. It means modernization of raw-material industries on the new technological bases.
\end{abstract}

Keywords - Geo-ecology; industrial clusters; Kuzbass; neoindustrialization; economic instruments; social well-being

\section{INTRODUCTION}

At the present stage of social and economic development of Russia the role of large industrial clusters like Kuzbass (Western Siberia, Russia) is getting significantly increased in stabilization of economic growth, improving of the international competitiveness of Russia, rise of social wellbeing of the Russians.

The Russian economy is about to start the "new industrialization" connected with innovative development of key industries, including raw-material extracting [1]. It is impossible to expand the financial base and regulating instruments of the government, to form the innovative clusters of high technologies without using the investment potential of industrial clusters.

However, the restoring and development of industrial potential of the Russian economy inevitably causes a number of negative "sidereal effects", among which the deterioration of an ecological situation of large industrial agglomerations as the most important one [2]. As a result, the main problem of social and economic development (growth of social wellbe- ing) doesn't find the solution, and the gap in life conditions between the Russians and residents of technologically advanced countries goes deep, the social and demographic situation worsens, the need for government financing of health care and compensation of ecological damage increase. The problem of geo-ecological factor considered in industrial policy led to the fact that a number of the BRICS countries (mainly Brazil and China) have already faced ecological restrictions of economic growth [3].

\section{MATERIALS AND METHODS}

The need of stabilization of the growth in Russian economy, modernization of the national economy, innovative development of industrial clusters is considered in works of Russian economists V.L. Inozemtsev [4], S.S. Gubanov [5], S.Yu. Glazyev [6], A.S. Neshitoy [7], O. Rogova [8], A.I. Tatarkin [9], V.A. Tsvetkov [10], etc. D. Bell [11], R. Reich [12], C. Clark [13] etc. pay special attention to similar problems.

Matters of social wellbeing are object of research of A. Diton [14], D. Asemoglu [15], U. Akcigit etc.; in Russia G.A. Barysheva [16], M.A. Gasanov [17], A.G. Grandberg [18] etc.

Problems of impact of economic growth on environment are mainly investigated by foreign scientists - P. Schulte [19], S. Pandalai, V. Wulsin, H. Chun, J. Harter [20], V. Gurley, L. Berkman [21], T. Glass, I. Brissette, T. Seeman etc.

At the same time, the lack of system comprehension of geo-environmental problems of economic growth and industrial development is obvious; the difference in opinion about the role of the government regulation of ecological "external effects" of economic growth is observed.

So we propose the neo-industrialization of economy as the discourse of solving geo-ecological problems and raise of social well-being for inhabitants of industrial clusters. It means not only significant changes in its technology and industry structure (development of new high-tech industries, the integration of science and production), but above all carrying out systematic and complex industrial, ecological and social policy of the state. It also concerns generating economic relations in the area of investment, accumulation of capital resources, expanding production and distribution of processed 
product. Such neo-industrial structural changes should affect the social and ecological basis of national economy system, the spatial distribution of productive forces and technological basis of economy.

The need for development of a set of measures for considering and solution of geo-environmental problems has risen badly in industrial clusters of the Urals, Western and Eastern Siberia, where coal, oil and gas companies, metallurgical, chemical enterprises have the immense destructive impact on the environment [22, 23, 24].

Relevance of fundamental researches of geoenvironmental problems of social and economic development of industrial clusters is dictated by the following problems of the government economic policy:

1. Absence of a technological platform of the geo-ecology of industrial clusters uniting the research capacity of technical universities and productive and economic opportunities of the industrial enterprises.

2. An insufficient readiness of theoretical provisions applying to geo-ecological factor of technological modernization of Russian industry and development of import substitution in key branches therefore ecological restrictions of economic growth can repeatedly increase [25, 26].

3. Inconsistency of mechanisms of the Government policy of import substitution, innovative development and stimulation of economic growth, greening of industrial clusters and the increase in social wellbeing in Russia.

4. Weak reflection of the provision of a geo-ecological factor of development of industrial clusters in the main economic program documents of the Government of the Russian Federation, including "Strategy of innovative development of the Russian Federation for the period till 2020", "The forecast of scientific and technological development of the Russian Federation for a long-term outlook", "The concept of longterm social and economic development of the Russian Federation for the period till 2020" [27].

\section{RESULTS}

The methodology of the planned research is presented by general scientific and special methods of economics:

- promotion of a hypothesis of an economic growth dichotomy and negative impact on environment;

- generalization of concrete historical specifics of the geoecological problems caused by industrial revolution, the emerging development (industrialization) and innovative development ("new industrialization");

- logical analysis of communications of geo-ecological problems and economic dynamics;

- structural and dynamic analysis of formation and development of industrial clusters, changes of national accounts, growth of social wellbeing and increase of geo-ecological problems.

Formation of theoretical bases and development of practical recommendations means synthesis of the basic methodo- logical and theoretical provisions of a paradigm of the balanced participation of the state in regulation of economic development offered by representatives of the Keynesian, neoclassical, institutional, structuralism directions of economic science, and also Russian and foreign scientists - authoritative experts in problems of the analysis of structure of national reproduction, economic dynamics, development of technological basis of economy, development of the purposes, the priority directions and tools of structural policy.

\section{DISCUSSION}

A number of indicators of geo-ecological threats must include creation of a technological platform of industrial clusters geo-ecology, formation of the priority technologies list for advancing solution of geo-ecological problems of social and economic development, improvement of the mechanism of public and private partnership in the area of industrial enterprises' ecology, development of the Government regulations for geo-ecological component of social wellbeing of the Russians.

The advanced geo-ecological regulation of social and economic development of industrial clusters plays an important role in import substitution development which is expected to enforce the environmental damages in such key industries as nonferrous metallurgy, organic chemistry, oil processing, coal chemistry, mechanical engineering.

All this increases the role of technical universities and creative researchers' teams in the areas of technological and environmental problems' influence on social and economic development.

The assessment of the geo-ecological factor assumes the use of methods of background and monitoring of impact on environment of the enterprises forming "core" of industrial clusters in dynamics of change in macro- and meso-economic indicators and in connection with criteria of social wellbeing.

The general recommendations for studying of geoecological problems in industrial clusters of Western Siberia and projecting of their solving must include three stages: search, analysis and prediction, presentation and organization.

At the first search stage, the following issues must be highlighted [28]:

- collection of information about sources of negative influence on environment of the "core" enterprises of industrial clusters of Russia, about dynamics of indicators of land use, ecological influence, cluster and national economic indicators, criteria of social wellbeing;

- carrying out economic and statistical analysis of the received indicators and creation of model impact of geoecological factors of social and economic development of industrial clusters on social wellbeing of the Russians;

- formation of the concept of considering of geoecological factors of social and economic development of Russia, which assumes Government regulation of economy in industrial clusters, in compliance with structural proportions and technological determinants of innovative development, taking into account target geo-ecological indicators, methods 
of strategic indicative planning, innovative import substitution, growth of social wellbeing.

At the second, analysis and prediction stage the following matters must be explored:

- development of methodological and theoretical provisions of research of geo-ecological factors of social and economic development of Russia. They are urged to make a basis of the theory of the balanced combinatory and innovative development of key branches of Russian industry in a section of industrial clusters with minimization of ecological damage and decrease in social wellbeing of Russians as a result of action of not economic factors;

- formation of methods of the advanced forecasting of geo-environmental problems of economic growth and development of suggestions for improvement of mechanisms of Government ecological regulation, stimulation of economic growth and placement of productive forces;

- the offering of a complex of geo-ecological criteria of an assessment of innovative development of industrial clusters, considering imperatives of stabilization of economic growth and increase of social wellbeing of Russians; application and adaptation of these criteria at the regional level;

At the third, presentation and organization, stage the following results should be obtained:

- development of strategy of innovative geo-ecologically balanced development of industrial clusters in Russian economy;

- organization of network scientific laboratory of a geoecologically balanced innovative development of industrial clusters on the basis of interactions between leading scholars from Russian and foreign technical universities;

- presentation of the basic theoretical conclusions and practical recommendations devoted to considering geoecological factors of industrial clusters development to state authorities for a technological platform of geo-ecology of industrial clusters installing.

The proposed strategy of advanced solution of geoecological problems in neo-industrial clusters is neoindustrially oriented and includes the following statements.

The first statement is a shift of relation model between the state and business from "participation in governing" to "participation in innovation";

The second statement is encouraging the involvement of the basic (intellectual, energy), and internal (financial, marketing resources, materials and equipment) in the neoindustrial transformation of cluster's economy during development of innovative cross-platform and inter-cluster interactions.

The third statement is creating conditions for long-term growth of social well-being and improving of geo-ecological situation in the process of recovery of manufacturing industries based on a new technology.
The stages of implementation of neo-industrial strategy of geo-ecological problems solving include the following elements.

The first element is innovative development of competitive raw material production which will be able to decrease harmful influence on environment.

The second element is investing in modernization of processing industries and high-tech demand growth. This allows replacing raw-material production as the main part of gross regional product (up to $70 \%$ in Kuzbass) with processed goods [29].

The third strategic element is an innovative breakthrough in the process of inter-sectoral and inter-cluster transfer of converged technologies.

The essence of the convergence of technologies consists in the interpenetration and the combination of different technological innovations, united by a common digital form design, printing and diffusion [30, 31]. Also, technological convergence means the development of existing clusters of multiplatform innovations developed in different technological platforms, but able to give a common product. We have identified the following areas of convergent technologies appropriate for Kuzbass neo-industrial cluster:

1. Technologies derived from the fusion of biochemistry and energy (bioenergy), allowing to go to non-waste production technologies of environmentally clean fuel and replace non-renewable hydrocarbon resources for the nearest future.

2. Technologies that unite processors manufacturing and software making (distributed computing). They will be able to create an integrated telecommunications network, significantly advance different kinds of engineering and accelerate the development of new technology samples by design of multivariate computer simulation.

3. Laser informatics technologies that can create a data repository, surpassing modern ones in thousands of times. This will speed up the digitization of technological basis of industry, initiate robotics for such traditional Kuzbass industries as coal, oil and gas, chemical industry, power system.

We also proposed the instruments of implementing the strategy of geo-ecological problems solving during neoindustrial transformation of Kuzbass economy:

- emission instruments - money emissions by The Central Bank for the formation of inter-bank lending fund for hightech enterprises and holdings financing at negative real interest rates with the security of shares, bonds of subordinated targeted government debt;

- credit instruments - differentiation of discount rate for commercial banks incorporated in high-tech holdings financing industrial innovation investment projects, interest rate subsidies and public investment lending for high-tech industries;

- investment and insurance instruments - formation of public-and-private banking venture funds and pools and investment funds of technology platforms, the creation of the 
state guarantee fund for venture capital investment and stateowned insurance venture.

\section{CONCLUSIONS}

So geo-ecological problem solving strategy requires neoindustrial transformation of property relations in the process of vertical integration of raw material and processing companies, financial firms, $R \& D$ organizations, the formation of high-tech holdings of the banking type with state participation.

All the instruments of the strategy of advanced geoecological problem solving require institutional conditions such as giving the status of structural reforms guarantor to the state; development and adoption of laws regulating innovation, investment, venture banks, investment consortiums of public transferred technologies; targeting programs for technology transfer in foreign direct investment; the establishment of high-tech lobby; maximizing preferential tax regime for innovative firms-contractors of industrial enterprises; development of innovative entrepreneurship and subcontracting; state insurance of industrial innovation investment.

The approachability of the announced purpose and achieving the set goals is explained by the geo-economic scholar studying of neo-industrial transformations, innovative development of industrial clusters in Kuzbass State Technical University.

\section{ACKNOWLEDGEMENTS}

The authors express their gratitude to the staff of Open Pit Mining Department of the T.F. Gorbachev Kuzbass State Technical University, the staff of Economy Department of National Research Tomsk Polytechnical University. The author also expresses his sincere appreciation and gratitude to V.A. Kovalev for his significant personal involvement and support.

\section{REFERENCES}

[1] Zhironkin S.A. Factoring and leasing development at coal mining industry of Kuzbass as an important element of its financial part. Ugol', 2001, vol. 4, pp. 29-30.

[2] Tyulenev M.A., and Lesin Y.V. Justification complex purification technology open-pit mines wastewater. Taishan Academic Forum Project on Mine Disaster Prevention and Control, 2014, pp. 441-444.

[3] Lesin Y.V., Lukyanova S.Y. and Tyulenev M.A. Mass transfer of dispersed particles in water filtration in macro-grained media. Journal of Mining Science, 2010, vol.46 (1), pp. 78-81.

[4] Inozemcev V.L. Sovremennoe postindustrial'noe obshhestvo: priroda, protivorechija, perspektivy [The modern postindustrial society: nature, contradictions, perspectives]. Moscow, Logos, 2000, 422 p.

[5] Gubanov S. To the policy of Russian economy neo-industrialization. Economist. 2009, vol 9, pp. 19-20.

[6] Glaziev S. "The Strategy-2020" - Anti- modernisation act. Russian Economic Journal, 2012, vol. 2, pp. 3-6.

[7] Neshitoy A. To the new model of economic development: reproducing aspect. Economist, 2010, Vol. 2, pp. 10-24.

[8] Rogova O. How privatization and new industrialization correspond? 2013, Economist. vol. 8, pp. 52-57.
[9] Tatarkin A., and Romanova O. About possibilities and mechanism of neo-industrialization of old industry areas. Economist, 2013, vol. 8, pp. 31-41.

[10] Tsvetkov V.A. Paradigma i "tochki rosta" novoj industrial'noj modernizacii [The paradigm and "points" of new industrial modernization of Russia]. Moscow, CEIM RAS, 2011, 268 p.

[11] Bell D. The coming of post-industrial society. Venture in social forecasting. N.Y., Collman Pub., 1973, 356 p.

[12] Reich R. The work of nations. Preparing ourselves for 21st Century capitalism. N.Y., Univ. of N.Y. Pub., 1992, 638 p.

[13] Clark C. The conditions of economic progress. London, Logan Pub., 1991,544 p.

[14] Deaton A. Income, health, and wellbeing around the world: Evidence from the Gallup World Poll. Journal of Economic Perspectives, 2008, vol. 22(2), pp. 53-72.

[15] Acemoglu D., Akcigit U., and Kerr W. Networks and the Macroeconomy: An Empirical Exploration. Harvard, Harvard Business School, 2015, $388 \mathrm{p}$.

[16] Barysheva G.A., and Novoselova E.G. Methodology of Application of the Structural Shift Mechanism for Regulation of the National Economic Management System. Applied Mechanics and Materials. 2014, Vol. 682, pp. 550-554.

[17] Gasanov M., Gasanov E. and Egorova M. The Technologies of the Network Prosperity in Russia. Procedia - Social and Behavioral Sciences, 2016, vol. 166, pp. 103-106

[18] Grandberg A. Strategija i problemy ustojchivogo razvitija Rossii v XXI-m veke [The strategy and the problems of steady development of Russia in XXI century]. Moscow, Ekonomika Pub., 2002, 266 p.

[19] Schulte P., Pandalai S., Wulsin V., and Chun H.,. Interaction of occupational and personal risk factors in workforce health and safety. Am. J. Public Health, 2012, vol. 102, pp. 434-448.

[20] Harter J., and Gurley V. Measuring wellbeing in the United States. Assoc. Psichol. Sci., 2008, vol. 12, pp. 23-26

[21] Berkman L., Glass T., Brissette I., and Seeman T. From social integration to health: Durkheim in the new millennium. Social Science and Medicine, 2000, vol. 51 (6), pp. 843-857.

[22] Tyulenev M, Zhironkin S., and Litvin O., The low-cost technology of quarry water purifying using the artificial filters of overburden rock. Pollution Research, 2015, vol. 34 (4).: pp 825-830.

[23] Zhironkin S.A. About measures of vexel circulation development and vexelability definition of fuel-and-power complex' enterprises. Ugol', 2002, vol. 4, pp. 47-48.

[24] Khoreshok A. On side cutting bit when operating at sheerer drums. Ugol', 2002, vol. 7, pp. 10-11.

[25] Tyulenev M., Lesin Y., Zhironkin S., and Garina E. Coal producers waste water purification. Metallurgical and Mining Industry. 2016, Vol. 2, pp. 52-56.

[26] Zhironkin S.A., Tyulenev M.A., Zhironkina O.V. and Hellmer M. The global determinants of mining higher education development. Metallurgical and Mining Industry, 2016, vol. 2, pp. 62-67

[27] Zhironkin S.A. Governmental factoring development of TEK Kuzbass. Ugol', 2001, vol. 6, pp. 62.

[28] Lesin Y.V., Luk'yanova S.Y. and Tyulenev M.A. Formation of the composition and properties of dumps on the open-pit mines of Kuzbass. IOP Conference Series: Materials Science and Engineering, 2015, vol. 91 (1), 012093.

[29] Zhironkin S.A. Prospects and new possibilities investment attracting to Kuzbass coal mining industry. Ugol', 2002, vol. 6, pp. 31-36.

[30] Aksenov V.V., Khoreshok A.A., Begljakov V.Y. Justification of Creation of an External Propulsor for Multipurpose Shield-Type Heading Machine - GEO-WALKER. Applied Mechanics and Materials, 2013, vol. 379, pp. 20-23.

[31] Melchers, K., Kretschmann Yu., Goerke-Mallet P., Kleineberg K., and Tyulenev M. Elementy i aspekty post-ekspluatatsionnogo perioda gornykh predpriyatij [Elements and aspects of post-operational period of mining enterprizes]. Vestnik Kuzbasskogo gosudarstvennogo tehnicheskogo universiteta, 2015, vol. 6, pp. 3-13. 